\title{
Strategic use of amino acid $N$-substituents to limit $\alpha$-carbon-centered radical formation and consequent loss of stereochemical integrity
}

\author{
Anna K. Croft, ${ }^{\dagger}$ Christopher J. Easton, ${ }^{*}$ Katherine Kociuba and Leo Radom* \\ Research School of Chemistry, Australian National University, Canberra, ACT 0200, Australia
}

Received 13 May 2003; accepted 13 June 2003

\begin{abstract}
Ab}$ initio calculations have been used to investigate the effect of $N$-substituents on the stability of $\alpha$-carbon-centered amino acid radicals. Optimized structures of glycine derivatives and related substituted methanes, and the corresponding radicals, were determined with B3-LYP/6-31G(d). Single-point RMP2/6-31G(d) calculations on these structures were then used to obtain radical stabilization energies, which were compared with the relative rates of formation of the same or closely similar radicals in reactions with $N$-bromosuccinimde. These studies show that $N$-acylation and sulfonation decrease both the stability and the ease of formation of the $\alpha$-carbon-centered radicals. Greater effects are seen with fluoroacyl, fluoroalkylsulfonyl and imido groups. The extent of the effect of the imido and fluoroalkylsulfonyl groups is such that $N$-phthaloyl- and trifluoromethanesulfonyl-protected amino acids react by hydrogen-atom abstraction from the side chain, thereby avoiding reaction at the chiral $\alpha$-center and preserving its stereochemical integrity. The origins of these substituent effects are examined.
\end{abstract}

(c) 2003 Elsevier Ltd. All rights reserved.

\section{Introduction}

The proteinogenic $\alpha$-amino acids and their derivatives constitute a readily available pool of optically active starting materials for asymmetric synthesis. ${ }^{1,2}$ They are particularly suitable for the preparation of a wide range of the non-proteinogenic amino acids that occur naturally, and have been shown to be active as enzyme inhibitors and other moderators of physiological activity. One way to elaborate $\alpha$-amino acids and their derivatives is through the use of free radical chemistry, ${ }^{3-5}$ but the principal limitation of this approach is the tendency for hydrogen-atom-transfer reactions of these compounds to afford $\alpha$-carbon-centered radicals as a result of their stability. Generally this leads to the destruction of the stereochemical integrity of the substrate. To overcome this, we have exploited the $\mathrm{N}$ phthaloyl protecting group for the side-chain functionalisation of amino acids. ${ }^{6-11}$ We have shown, for example, that reaction of the derivatives of valine 1a and leucine 2a with $N$-bromosuccinimide (NBS) gives

\footnotetext{
* Corresponding author. Tel.: +61-2-6125-8201; fax: +61-2-6125-8114; e-mail: easton@rsc.anu.edu.au

† Present address: Department of Chemistry, University of Wales, Bangor, Gwynedd LL57 2UW, UK.

* Present address: School of Chemistry, University of Sydney, Sydney, NSW 2006, Australia.
}

the corresponding bromides $\mathbf{1 b}$ and $\mathbf{2} \mathbf{b}$, without loss of stereochemistry. While it is clear that the phthaloyl substituent deactivates the $\alpha$-position of amino acids towards hydrogen abstraction, the effect has not been quantified and its origins have not been examined. We therefore set out to investigate this phthaloyl group effect using a combination of theoretical and experimental methods. During the course of this work, we identified the trifluoromethanesulfonyl (triflyl) group as another $N$-substituent that significantly deactivates the $\alpha$-position of amino acids towards radical formation, and we also evaluate this finding.

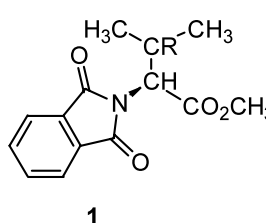

1

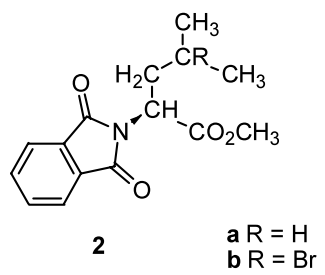

a $R=H$
b $R=B r$

\section{Results}

\subsection{Calculation of structures and radical stabilization energies}

The optimized structures of the glycine derivatives and 
the related substituted methanes $\mathbf{3 a}-\mathbf{g}, \mathbf{5 a}-\mathbf{g}, \mathbf{9 a}, \mathbf{b}, \mathbf{1 1 a}, \mathbf{b}$ and $\mathbf{1 3}$, and the corresponding radicals $4 \mathbf{a}-\mathbf{g}, \mathbf{6 a}-\mathbf{g}$, 10a,b, 12a,b and 14, were determined at the B3-LYP/6$31 \mathrm{G}(\mathrm{d})$ level. They are displayed in Figure 1 in the cases of the radicals 10a,b and 12a,b. Radical stabilization energies (RSEs) were calculated as the energy changes in the isodesmic reactions shown in Eq. (1):

$$
\mathrm{R}^{\bullet}+\mathrm{CH}_{4} \rightarrow \mathrm{RH}+\mathrm{CH}_{3} \cdot
$$

The RSEs correspond to the differences between the $\mathrm{C}-\mathrm{H}$ bond dissociation energies of methane and $\mathrm{RH},{ }^{12,13}$ and reflect the stability of $\mathrm{R}^{\circ}$ compared with $\mathrm{CH}_{3}{ }^{\circ}$ (relative to the corresponding closed-shell molecules). Our reported RSEs were determined through single-point RMP2/6-31G(d) calculations on the B3-LYP/6-31G(d) optimized structures, and correspond to values at $0 \mathrm{~K}$. Temperature corrections were not applied since they should show substantial cancellation for such reactions. ${ }^{14}$ Details of the theoretical
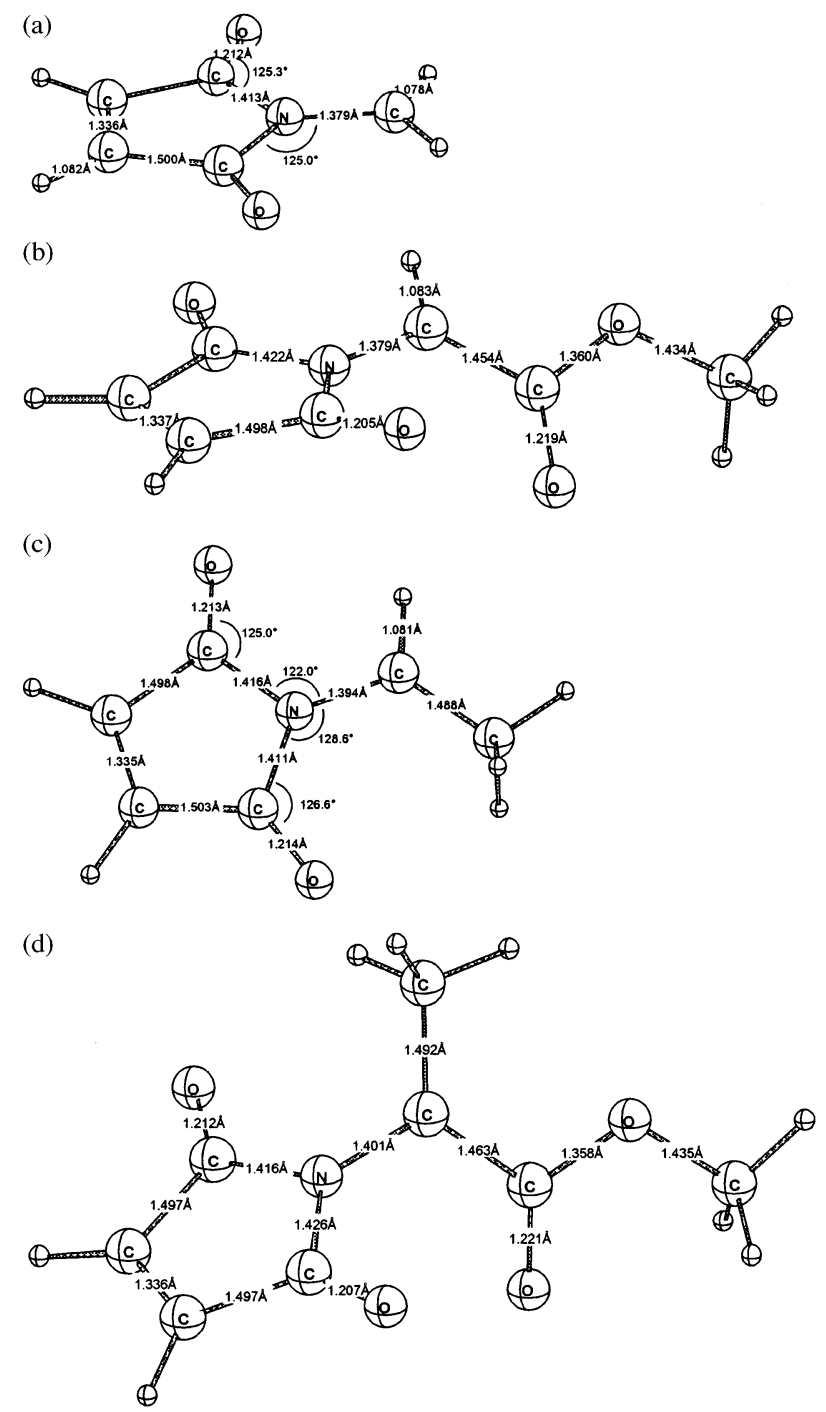

Figure 1. Optimized structures [B3-LYP/6-31G(d)] of a) the maleimidomethyl radical $\mathbf{1 0 a}, \mathrm{b})$ the $N$-maleylglycyl radical $\mathbf{1 2 a}$, c) the maleimidoethyl radical $10 \mathbf{b}$, and d) the $N$-maleylalanyl radical $\mathbf{1 2 b}$.
Table 1. Radical stabilization energies [0 K, RMP2/6$31 \mathrm{G}(\mathrm{d}), \mathrm{kJ} \mathrm{mol}^{-1}$ ] of substituted glycyl radicals and related substituted methyl radicals

$\mathrm{R}^{\bullet}+\mathrm{CH}_{4} \rightarrow \mathrm{RH}+\mathrm{CH}_{3} \quad \mathrm{RSE}$

\begin{tabular}{|c|c|c|}
\hline $4 \mathbf{a}\left(\mathrm{NH}_{2} \mathrm{CH}_{2}^{\circ}\right)$ & 3a & $44.7^{\mathrm{a}}$ \\
\hline 4b $\left(\mathrm{HCONHCH}_{2}{ }^{\circ}\right)$ & $3 \mathbf{b}$ & 36.9 \\
\hline $4 \mathrm{c}\left(\mathrm{CH}_{3} \mathrm{CONHCH}_{2}{ }^{\circ}\right)$ & $3 c$ & $37.4^{\mathrm{a}}$ \\
\hline 4d $\left(\mathrm{CF}_{3} \mathrm{CONHCH}_{2}\right)$ & 3d & 33.7 \\
\hline $4 \mathrm{e}\left(\mathrm{HSO}_{2} \mathrm{NHCH}_{2}{ }^{\circ}\right)$ & $3 e$ & 28.7 \\
\hline 4f $\left(\mathrm{CH}_{3} \mathrm{SO}_{2} \mathrm{NHCH}_{2}{ }^{\circ}\right)$ & $3 f$ & 28.0 \\
\hline $4 \mathrm{~g}\left(\mathrm{CF}_{3} \mathrm{SO}_{2} \mathrm{NHCH}_{2}^{\circ}\right)$ & $3 g$ & 25.4 \\
\hline 10a $\left(\right.$ MaleimidoCH ${ }_{2}^{\circ}$ ) & $9 \mathrm{a}$ & 28.5 \\
\hline 10b $\left(\right.$ MaleimidoCH $\left.{ }^{\circ} \mathrm{CH}_{3}\right)$ & 9b & 28.8 \\
\hline $14\left(\mathrm{CH}_{2}{ }^{\circ} \mathrm{CO}_{2} \mathrm{CH}_{3}\right)$ & 13 & $21.6^{\mathrm{a}}$ \\
\hline 6a $\left(\mathrm{NH}_{2} \mathrm{CH}^{\circ} \mathrm{CO}_{2} \mathrm{CH}_{3}\right)$ & $5 \mathbf{a}$ & 94.0 \\
\hline 6b $\left(\mathrm{HCONHCH}^{*} \mathrm{CO}_{2} \mathrm{CH}_{3}\right)$ & $5 \mathbf{b}$ & 79.6 \\
\hline 6c $\left(\mathrm{CH}_{3} \mathrm{CONHCH}^{\circ} \mathrm{CO}_{2} \mathrm{CH}_{3}\right)$ & $5 c$ & $82.2^{\mathrm{a}}$ \\
\hline 6d $\left(\mathrm{CF}_{3} \mathrm{CONHCH}^{*} \mathrm{CO}_{2} \mathrm{CH}_{3}\right)$ & 5d & 72.8 \\
\hline 6e $\left(\mathrm{HSO}_{2} \mathrm{NHCH}^{\circ} \mathrm{CO}_{2} \mathrm{CH}_{3}\right)$ & $5 e$ & 72.5 \\
\hline 6f $\left(\mathrm{CH}_{3} \mathrm{SO}_{2} \mathrm{NHCH}^{\circ} \mathrm{CO}_{2} \mathrm{CH}_{3}\right)$ & $5 f$ & 74.0 \\
\hline $6 \mathbf{g}\left(\mathrm{CF}_{3} \mathrm{SO}_{2} \mathrm{NHCH}^{\circ} \mathrm{CO}_{2} \mathrm{CH}_{3}\right)$ & $5 g$ & 66.0 \\
\hline 12a (MaleimidoCH${ }^{\circ} \mathrm{CO}_{2} \mathrm{CH}_{3}$ ) & $11 a$ & 33.2 \\
\hline 12b (MaleimidoC $\left(\mathrm{CH}_{3}\right) \mathrm{CO}_{2} \mathrm{CH}_{3}$ ) & 11b & 46.0 \\
\hline
\end{tabular}

a These data are consistent with literature values. ${ }^{12,14,15}$

results (presented as Gaussian archive files) are available as Supplementary Information from the authors. The RSEs for the radicals $4 \mathbf{a}-\mathbf{g}, \mathbf{6 a}-\mathbf{g}, \mathbf{1 0 a}, \mathbf{b}, \mathbf{1 2 a}, \mathbf{b}$ and $\mathbf{1 4}$ are presented in Table 1.

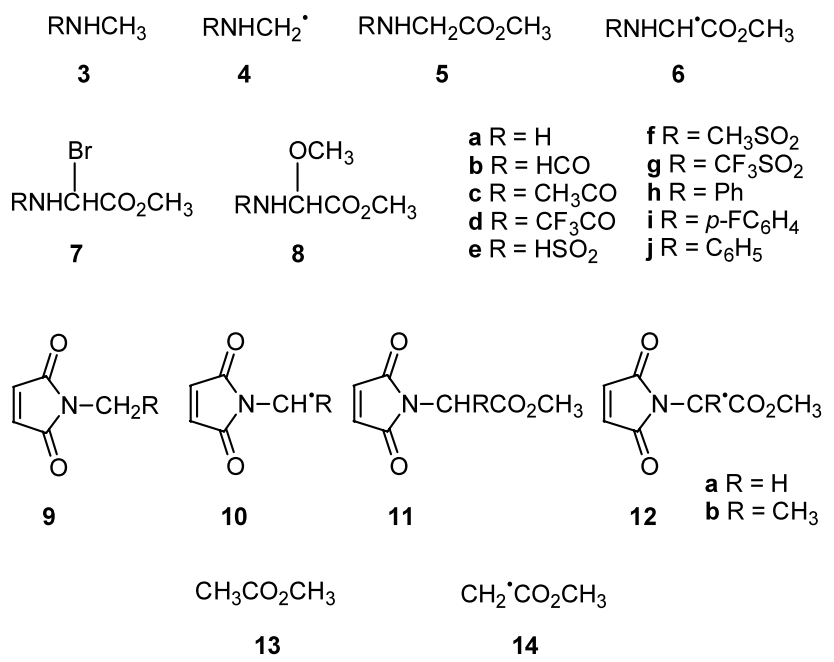

The glycyl radical 6a was studied as a simple example of an $\alpha$-carbon-centered amino acid radical. The radicals $\mathbf{6 b}-\mathbf{f}$ were included for comparison in order to investigate the effects of acylation and sulfonation of the amino group. The maleimides 12a,b were examined as simple models for $N$-phthaloylamino acid radicals, with and without a side chain. The related methyl-substituted radicals $\mathbf{4 a - g}$ and $\mathbf{1 0 a}, \mathbf{b}$ are analogous to the glycine derivatives $6 \mathbf{a}-\mathbf{g}$ and 12a,b, except that they lack the methoxycarbonyl group. They were examined to determine the effect of the methoxycarbonyl substituent in combination with amino and substituted amino groups. The acetate radical $\mathbf{1 4}$ was also studied, to 
examine the effect of the methoxycarbonyl substituent alone.

\subsection{Measurement of reaction rates}

The reactions of the glycine derivatives $\mathbf{5 c}, \mathbf{5 d}, \mathbf{5 g}, \mathbf{5 h}$, $\mathbf{5 i}, \mathbf{5 j}$ and $\mathbf{1 5}$ with NBS in refluxing carbon tetrachloride under nitrogen were also studied. The amides $\mathbf{5 c}$ and $\mathbf{5 d}$, and the sulfonamide $\mathbf{5 g}$, were examined in order to make a direct comparison between the rates of reaction to give the radicals $\mathbf{6 c}, \mathbf{6 d}$ and $\mathbf{6 g}$ and the RSEs of these radicals. It was not practical to study the glycine ester 5a since the free amino group is incompatible with these reaction conditions. The phthalimide 15 was included to compare its rate of reaction with the RSE of the analogous maleimide 12a. The benzamides $\mathbf{5 h}, \mathbf{5 i}$ and $\mathbf{5 j}$ were also investigated, as a series where the effect of the fluorines on the ease of formation of the radicals $\mathbf{6 h}, \mathbf{6 i}$ and $\mathbf{6 j}$ could be probed. The amides $\mathbf{5 c}$, $\mathbf{5 d}, \mathbf{5 h}, \mathbf{5 i}$ and $\mathbf{5 j}$ gave the corresponding bromides $\mathbf{7 c}$, $\mathbf{7 d}, 7 \mathbf{h}, 7 \mathbf{i}$ and $\mathbf{7 j}$, presumably via the radicals $\mathbf{6 c}, \mathbf{6 d}, \mathbf{6 h}$, $\mathbf{6 i}$ and $\mathbf{6 j}$, respectively. The bromides $7 \mathbf{c}, \mathbf{7 d}, 7 \mathbf{h}, 7 \mathbf{i}$ and $7 \mathbf{j}$ were unstable so they were characterized as the corresponding $\alpha$-methoxyglycine derivatives $\mathbf{8 c}, \mathbf{8 d}, \mathbf{8 h}$, $\mathbf{8 i}$ and $\mathbf{8 j} .{ }^{16}$ Reaction of the sulfonamide $5 \mathbf{g}$ gave the succinimidylglycine 18. Presumably the bromide $\mathbf{7 g}$ is formed via the radical $\mathbf{6 g}$, but loses $\mathrm{HBr}$ more rapidly than the corresponding bromoglycines $\mathbf{7 c}, \mathbf{7 d}, \mathbf{7 h}, \mathbf{7 i}$ and $7 \mathbf{j}$, due to the greater acidity of the sulfonamide hydrogen. Succinimide then adds to the product sulfonylimine to give $\mathbf{1 8} .{ }^{16}$ Under the reaction conditions used, the phthaloylglycine derivative $\mathbf{1 5}$ was inert; none of the bromide 17a or the methoxyglycine derivative $\mathbf{1 7 b}$ was detected, indicating that the radical 16 does not form. The relative rates of reaction of the glycine derivatives $\mathbf{5 c}, \mathbf{5 d}, \mathbf{5 g}, \mathbf{5 h}, \mathbf{5 i}, \mathbf{5 j}$ and $\mathbf{1 5}$ to give the radicals $\mathbf{6 c}, \mathbf{6 d}, \mathbf{6 g}, \mathbf{6 h}, \mathbf{6 i}, \mathbf{6 \mathbf { j }}$ and $\mathbf{1 6}$ were determined in competitive experiments using limited quantities of the

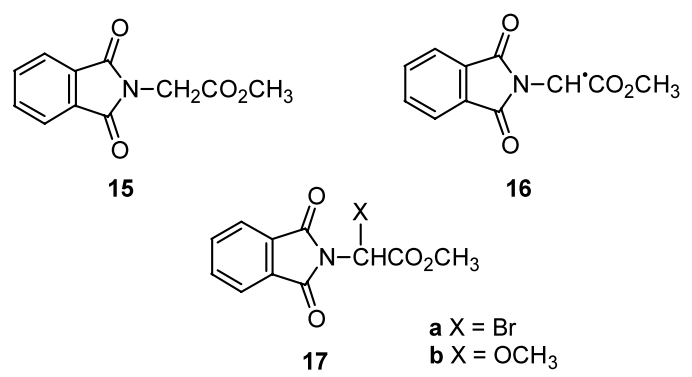

Table 2. Relative rates of reaction of amino acid derivatives with $N$-bromosuccinimide

\begin{tabular}{|c|c|c|c|}
\hline $\mathrm{RH}+\mathrm{NBS}$ & $\rightarrow$ & $\mathrm{RBr}+$ Succinimide & $k_{\text {rel }}$ \\
\hline 5c $\left(\mathrm{CH}_{3} \mathrm{CONHCH}_{2} \mathrm{CO}_{2} \mathrm{CH}_{3}\right)$ & & $7 \mathrm{c}$ & 1.2 \\
\hline 5d $\left(\mathrm{CF}_{3} \mathrm{CONHCH}_{2} \mathrm{CO}_{2} \mathrm{CH}_{3}\right)$ & & $7 d$ & 0.05 \\
\hline $5 \mathrm{~g}\left(\mathrm{CF}_{3} \mathrm{SO}_{2} \mathrm{NHCH}_{2} \mathrm{CO}_{2} \mathrm{CH}_{3}\right)$ & & $7 \mathrm{~g}$ & $<0.005$ \\
\hline 5h $\left(\mathrm{PhCONHCH}_{2} \mathrm{CO}_{2} \mathrm{CH}_{3}\right)$ & & $7 \mathrm{~h}$ & $1.0^{*}$ \\
\hline $5 \mathbf{i}\left(p-\mathrm{FC}_{6} \mathrm{H}_{4} \mathrm{CONHCH}_{2} \mathrm{CO}_{2} \mathrm{CH}_{3}\right)$ & & $7 \mathbf{i}$ & 0.86 \\
\hline $5 \mathbf{j}\left(\mathrm{C}_{6} \mathrm{~F}_{5} \mathrm{CONHCH}_{2} \mathrm{CO}_{2} \mathrm{CH}_{3}\right)$ & & $7 \mathbf{j}$ & 0.25 \\
\hline $15\left(\mathrm{PhthalimidoCH}_{2} \mathrm{CO}_{2} \mathrm{CH}_{3}\right)$ & & $17 \mathbf{a}$ & $<0.0005$ \\
\hline
\end{tabular}

* Assigned as unity. brominating reagent ${ }^{15}$ and the results are shown in Table 2.

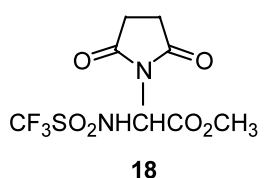

\section{Discussion}

The RSEs calculated in the present work for the radicals $\mathbf{4 a}, \mathbf{4 c}, \mathbf{6 c}$ and 14, are consistent with literature data. ${ }^{12,14,15}$ They show that the amino substituent in the radical $4 \mathrm{a}$ has a stabilizing effect of $44.7 \mathrm{~kJ} \mathrm{~mol}^{-1}$. $N$-Acylation and the consequent decrease in the $\pi$-electron-donating ability of the amido substituent reduces the RSE by $7-8 \mathrm{~kJ} \mathrm{~mol}^{-1}$, to 36.9 and $37.4 \mathrm{~kJ} \mathrm{~mol}^{-1}$ for the formamidomethyl and acetamidomethyl radicals $\mathbf{4 b}$ and $\mathbf{4 c}$, respectively. The even greater decrease in the electron-donating ability of an imido substituent further reduces the RSE by about $8-9 \mathrm{~kJ} \mathrm{~mol}^{-1}$, to $28.5 \mathrm{~kJ}$ $\mathrm{mol}^{-1}$ for the maleimide 10a. For similar reasons, $\mathrm{N}$ sulfonation reduces radical stability more effectively than acylation, by about $8-10 \mathrm{~kJ} \mathrm{~mol}^{-1}$, as illustrated by a comparison of the RSEs of the amides $\mathbf{4 b}$ and $\mathbf{4 c}$ and the sulfonamides $\mathbf{4 e}$ and $\mathbf{4 f}$. The correlation between the electron-donating ability of amino, amido and sulfonamido groups and radical stability is also apparent from the effect of the halogens on the RSEs of the radicals $\mathbf{4 b - g}$. The inductively electron-withdrawing fluorines of the trifluoroacetamide $\mathbf{4 d}$ reduce its RSE by 3-4 $\mathrm{kJ} \mathrm{mol}^{-1}$, to $33.7 \mathrm{~kJ} \mathrm{~mol}^{-1}$, relative to the corresponding values of 37.4 and $36.9 \mathrm{~kJ} \mathrm{~mol}^{-1}$ for the acetamide $\mathbf{4} \mathbf{c}$ and the formamide $\mathbf{4 b}$. Similarly the RSE of the triflamide $4 \mathrm{~g}$ is $2-4 \mathrm{~kJ} \mathrm{~mol}^{-1}$ lower than those of the corresponding non-fluorinated analogues $\mathbf{4 e}$ and $\mathbf{4 f}$.

The methoxycarbonyl group has a stabilizing effect in the radical 14 of $21.6 \mathrm{~kJ} \mathrm{~mol}^{-1}$, but its effect on the stability of the glycyl radical $\mathbf{6 a}$ is much greater. With an RSE of $94.0 \mathrm{~kJ} \mathrm{~mol}^{-1}$, the amino and methoxycarbonyl groups in this species provide a synergistic or captodative stabilization ${ }^{15,17-19}$ that is $27.7 \mathrm{~kJ} \mathrm{~mol}^{-1}$ more than the sum of their individual contributions to the RSEs of the radicals $4 \mathbf{a}\left(44.7 \mathrm{~kJ} \mathrm{~mol}^{-1}\right)$ and $\mathbf{1 4}(21.6$ $\left.\mathrm{kJ} \mathrm{mol}^{-1}\right)$. The effects of the amino, amido and sulfonamido groups on the stability of the glycyl radicals $6 \mathbf{b}-\mathbf{g}$ and 12a follow a similar trend to their effects on the corresponding methyl radicals $\mathbf{4 b}-\mathbf{g}$ and $\mathbf{1 0 a}$, but the magnitude is larger. Whereas acylation and sulfonation reduces the stability of the aminomethyl radical $4 \mathbf{a}$ by $7-8$ and $16-17 \mathrm{~kJ} \mathrm{~mol}^{-1}$, respectively, the effects on the stability of the glycyl radical $\mathbf{6 a}$, as represented by the RSEs of the radicals $\mathbf{6 b}, \mathbf{6 c}, \mathbf{6 e}$ and $\mathbf{6 f}$, are $12-15$ and $20-22 \mathrm{~kJ} \mathrm{~mol}^{-1}$. As discussed above, the fluorines of the substituted aminomethyl radicals $4 \mathbf{d}$ and $\mathbf{4 g}$ reduce the RSEs by $2-4 \mathrm{~kJ} \mathrm{~mol}^{-1}$, but comparison of the RSEs of the glycyl radicals $\mathbf{6 b}-\mathbf{g}$ shows that the effect of the halogens is much larger in these systems, being 7-10 kJ $\mathrm{mol}^{-1}$ for the amides $\mathbf{6 b}-\mathbf{d}$ and $6-8 \mathrm{~kJ} \mathrm{~mol}^{-1}$ for the sulfonamides $\mathbf{6 e - f}$. In all of the radicals $\mathbf{6 a - g}$, the $\pi$-electron-withdrawing methoxycarbonyl group mag- 
nifies the extent to which the $\pi$-electron-donating ability of the amino, amido and sulfonamido substituents is reflected in the RSEs.

The maleyl substituent decreases the RSE of the radical 10a by $16.2 \mathrm{~kJ} \mathrm{~mol}^{-1}$ relative to that of the aminomethyl radical 4a. Again the methoxycarbonyl group increases the extent of this effect, to $60.8 \mathrm{~kJ} \mathrm{~mol}^{-1}$, as shown by the difference between the RSEs of the radicals $\mathbf{6 a}$ and 12a, of 94.0 and $33.2 \mathrm{~kJ} \mathrm{~mol}^{-1}$, respectively. However, in this case the cause of the increase is quite different. The radicals $4 \mathbf{a}-\mathbf{g}, \mathbf{6 a}-\mathbf{g}$ and $\mathbf{1 0 a}$ are each able to adopt a minimum energy conformation in which there is good overlap of the $\pi$-orbitals of the substituent or substituents with the semi-occupied p-orbital at the radical center. This is illustrated in Figure 1a for the imidomethyl radical 10a which is planar with $C_{2 v}$ symmetry. By contrast, the minimum energy conformation of the maleylglycyl radical 12a is non-planar (Figure 1b) as a result of steric repulsion between the imide and ester oxygens. This limits the extent of orbital overlap that stabilizes the radical 12a and decreases the RSE much more than might otherwise have been expected.

The extra methyl group of the radical $\mathbf{1 0 b}$ does not significantly increase its RSE relative to that of the imidomethyl radical 10a. Any stabilization provided by the methyl group is offset by the strain associated with interactions between the methyl group and imide oxygens. This strain is evident from the distortion of the bond angles about the imide nitrogen, as shown in Figure 1c, and the $\mathrm{C}(\mathrm{O})-\mathrm{N}-\mathrm{C} \alpha-\mathrm{C} \beta$ torsion angle of $6.64^{\circ}$. The $\alpha$-methyl group of the alanyl radical $\mathbf{1 2 b}$ increases its RSE by $12.8 \mathrm{~kJ} \mathrm{~mol}^{-1}$ relative to that of the glycyl radical 12a, as is typical of the effect of an alkyl substituent. The minimum energy conformation of the alanyl radical 12b (Figure 1d) is distorted from planarity, like that of the glycyl radical 12a, but there is no indication that the side chain of $\mathbf{1 2 b}$ increases the extent of this distortion.

There is a strong correlation between the RSEs of the radicals $\mathbf{6 c}, \mathbf{6 d}, \mathbf{6 g}$ and 12a (Table 1), and the relative rates of reaction of the glycine derivatives $\mathbf{5 c}, \mathbf{5 d}, \mathbf{5 g}$ and $\mathbf{1 5}$, to give the radicals $\mathbf{6 c}, \mathbf{6 d}$ and $\mathbf{6 g}$ and the phthaloyl analogue 16 of the maleyl radical 12a (Table 2). There is also a direct correlation with the $\mathrm{p} K_{\mathrm{a}} \mathrm{s}$ of the acids corresponding to the acyl and sulfonyl groups of $\mathbf{5 c}, \mathbf{5 d}$ and $\mathbf{5 g}$. These $\mathrm{p} K_{\mathrm{a}} \mathrm{s}$ decrease principally as a result of increased stabilization of the conjugate bases due to greater electron delocalization. This parallels the extent of delocalization of the nitrogen electrons by the acyl and sulfonyl groups, which is inversely proportional to the electron-donating ability of the nitrogen to the radical center. Thus, the $\mathrm{p} K_{\mathrm{a}} \mathrm{s}$ of acetic acid, trifluoroacetic acid and triflic acid decrease in order from 4.7 to 0.3 to -5.5 , while the RSEs and relative rates of formation of the $N$-acetyl-, trifluoroacetyl- and triflyl-glycyl radicals $\mathbf{5 c}, \mathbf{5 d}$ and $\mathbf{5 g}$ decrease from 82.2 to 72.8 to 66.0 $\mathrm{kJ} \mathrm{mol}^{-1}$, and from 1.2 to 0.05 to $<0.005$, respectively. A similar correlation is apparent for the radicals $5 \mathbf{h}-\mathbf{j}$, where the $\mathrm{p} K_{\mathrm{a}} \mathrm{s}$ of benzoic acid, $p$-fluorobenzoic acid and pentafluorobenzoic acid decrease in order from 4.2 to 3.8 to 1.5 , while the relative rates of formation of the $N$-benzoyl-, $p$-fluorobenzoyl- and pentafluorobenzoylglycyl radicals $\mathbf{5 h}-\mathbf{j}$ decrease from 1.0 to 0.86 to 0.25 .

Of the systems examined in this study, apart from imidation, triflation appears to be the most effective way to reduce the RSEs and ease of formation of amino acid $\alpha$-carbon-centered radicals. Analogously to the behavior seen with the corresponding phthalimides, with the $N$-triflyl-substituted dipeptide 19a and the derivatives of valine 20a and phenylalanine 21a, triflation was sufficient to prevent reaction with NBS adjacent to the nitrogen. Reaction instead occurred to give the glycylbromoglycine derivative $19 \mathrm{~b}$ (which was characterized as the methoxide 19c), the $\beta$-bromovaline derivative $\mathbf{2 0 b}$, and a 1:1 mixture of diastereomers of the $\beta$-bromophenylalanine derivative 21b. With sulfuryl chloride, the valine derivative 20a gave a mixture of the $\beta$ chlorovaline derivative 20d and the corresponding diastereomeric $\gamma$-chlorovaline derivatives, in the ratio 1.3:1:1. Reduction of the bromide 20b with tributyltin hydride afforded 20a with the same optical rotation as that of the sample used to prepare the bromide $\mathbf{2 0 b}$, establishing that the side-chain halogenation occurs without loss of stereochemical integrity.

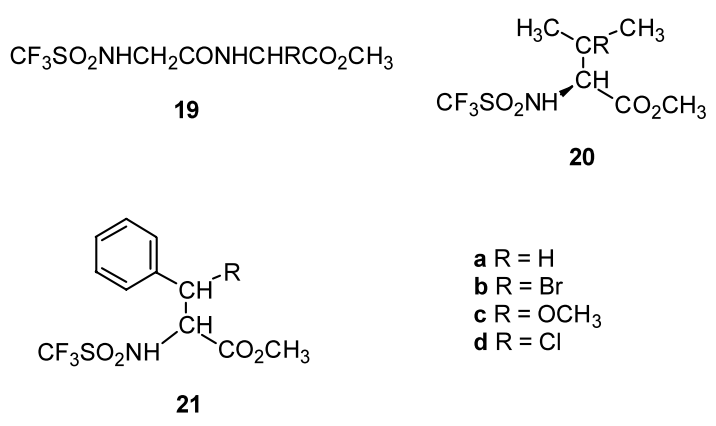

4. Concluding remarks

These theoretical and experimental results suggest that $N$-phthaloyl- and triflyl-amino acid derivatives are sufficiently protected against hydrogen-atom abstraction from the $\alpha$-position, for their stereochemical integrity to be preserved at that site while free radical reactions take place elsewhere on these molecules. Factors that affect the relative RSEs of the amino-, triflamido- and imidosubstituted radicals $\mathbf{4 a}, \mathbf{4 g}, \mathbf{1 0 a}, \mathbf{6 a}, \mathbf{6 g}$ and $\mathbf{1 2 a}$, are likely to contribute to these effects. Specifically, the lower $\pi$-electron-donating ability of either an imide or a triffamide, as well as the inability of imido and carboxy substituents to assume a coplanar arrangement about a carbon radical center, as required for optimal orbital overlap, leads to reduced radical stability.

\section{Theoretical and experimental procedures}

\subsection{Computational details}

Standard ab initio molecular orbital theory and density 
functional theory calculations were performed with Gaussian $94^{20}$ and MOLPRO $96 .{ }^{21}$ For the larger systems, preliminary conformational work was carried out at AM1 using the Spartan and MacSpartan Plus programs, in order to select the most appropriate conformations. The calculated results correspond to isolated molecules in the gas phase.

Optimized structures and harmonic vibrational frequencies were determined at the B3-LYP/6-31G(d) level. The structures were confirmed to be true local minima by means of the vibrational frequency calculations that showed all the frequencies to be real. Zero-point vibrational energies were obtained by scaling the B3-LYP/6$31 \mathrm{G}(\mathrm{d})$ values by $0.9806 .{ }^{22}$ Single-point RMP2/6-31G(d) calculations on the B3-LYP/6-31G(d) structures [RMP2/6-31G(d)//B3-LYP/6-31G(d)] were used to obtain improved relative energies. This approach has been found in previous work to produce radical stabilization energies (RSEs) of useful reliability. ${ }^{13}$

\subsection{General}

Melting points were determined on a Kofler hot-stage melting-point apparatus under a Reichert microscope and are uncorrected. Microanalyses were performed by the Research School of Chemistry Microanalytical Service at the Australian National University, on a CarloErba 1106 autoanalyser. Nuclear Magnetic Resonance (NMR) spectra were recorded in $\mathrm{CDCl}_{3}$ on either a Varian Gemini 300 or a Varian VXR 500S spectrometer. Electron impact (EI) mass spectra were obtained using either a VG Autospec double-focusing trisector mass spectrometer operating at $70 \mathrm{eV}$ or a Vacuum Generators ZAB2-SEQ mass spectrometer. Electrospray (ES) mass spectra were recorded on a VG Quatro 2 triple-quadrupole mass spectrometer. Optical rotations were measured using a Perkin Elmer 241 polarimeter.

Preparative chromatography was performed using either dry flash column chromatography ${ }^{23}$ or radial chromatography on a Harrison research model 7924T chromatotron, with Merck Kieselgel $60 \mathrm{PF}_{254}$ containing gypsum, eluting with a gradient of ethyl acetate/ hexanes. An Osram Ultra-Vitalux (240 V, 300 W, E27) sunlamp was used as the light source, to initiate radical reactions, at a distance of between 5 and $10 \mathrm{~cm}$ from the reaction vessel. Organic extracts were dried using anhydrous magnesium sulfate.

Glycine, glycylglycine, $(S)$-valine and phenylalanine were purchased from Aldrich Chemical Co. The glycine derivatives $\mathbf{5 c}, \mathbf{5 d}, \mathbf{5 g}, \mathbf{5 h}, \mathbf{5 i}, \mathbf{5 j}$ and $\mathbf{1 5}$ were prepared from glycine using standard methods and had physical and spectroscopic data consistent with those reported previously. ${ }^{7,24-26}$

5.2.1. Treatment of the glycine derivatives $5 \mathrm{c}, 5 \mathrm{~d}, 5 \mathrm{~g}, 5 \mathrm{~h}$, 5i, 5j and 15 with NBS. A mixture of the glycine derivative $(0.42 \mathrm{mmol})$ and NBS $(80 \mathrm{mg}, 0.45 \mathrm{mmol})$ in $\mathrm{CCl}_{4}(5 \mathrm{ml})$ was heated at reflux for $0.5-3 \mathrm{~h}$, under nitrogen, whilst being irradiated with a sunlamp. The mixture was then cooled to room temperature and filtered, and the filtrate was concentrated under reduced pressure. This afforded the $\alpha$-bromoglycine derivatives $7 \mathbf{c}, 7 \mathbf{d}, 7 \mathbf{h}, 7 \mathbf{i}$ and $7 \mathbf{j}$, from $5 \mathbf{c}, 5 \mathbf{d}, 5 \mathbf{h}, 5 \mathbf{i}$ and $5 \mathbf{j}$, respectively. These bromides were unstable so they were characterized as the corresponding methoxides 8c, 8d, $\mathbf{8 h}, \mathbf{8 i}$ and $8 \mathbf{j}$, through addition of methanol to the corresponding crude reaction products. ${ }^{15}$ Reaction of the sulfonamide $\mathbf{5 g}$ gave the succinimide $\mathbf{1 8}$, which was isolated through chromatography. The phthalimide $\mathbf{1 5}$ was recovered unchanged under these reaction conditions.

5.2.1.1. $N$-Acetyl- $\alpha$-bromoglycine methyl ester 7 c. Pale brown oil, $\delta_{\mathrm{H}} 2.10(3 \mathrm{H}, \mathrm{s}), 3.87(3 \mathrm{H}, \mathrm{s}), 6.48(1 \mathrm{H}, \mathrm{d}$, $J=10.0)$ and $7.10(1 \mathrm{H}$, br d, $J=10.0)$.

5.2.1.2. $N$-Acetyl- $\alpha$-methoxyglycine methyl ester $8 c$. (74\% from 5c) Colorless needles from ethyl acetate/hexanes, mp $44-45^{\circ} \mathrm{C}\left(\right.$ lit. $\left.^{27} 44-46^{\circ} \mathrm{C}\right) ; \delta_{\mathrm{H}} 2.10(3 \mathrm{H}, \mathrm{s}), 3.46$ $(3 \mathrm{H}, \mathrm{s}), 3.82(3 \mathrm{H}, \mathrm{s}), 5.53(1 \mathrm{H}, \mathrm{d}, J=9.0)$ and $6.80(1 \mathrm{H}$, br d, $J=9.0$ ).

5.2.1.3. $N$-Trifluoroacetyl- $\alpha$-bromoglycine methyl ester 7d. Pale brown oil, $\delta_{\mathrm{H}} 3.94(3 \mathrm{H}, \mathrm{s}), 6.36(1 \mathrm{H}, \mathrm{d}$, $J=10.0)$ and $7.10(1 \mathrm{H}$, br d, $J=10.0)$.

5.2.1.4. $N$-Trifluoroacetyl- $\alpha$-methoxyglycine methyl ester 8d. ( $80 \%$ from 5d) Colorless solid from ethyl acetate/hexanes, $\mathrm{mp} 96-99^{\circ} \mathrm{C}$ (Found: $\mathrm{C}, 33.58 ; \mathrm{H}$, 3.88; $\mathrm{N}, 6.63 . \mathrm{C}_{6} \mathrm{H}_{8} \mathrm{~F}_{3} \mathrm{NO}_{4}$ requires $\mathrm{C}, 33.48 ; \mathrm{H}, 3.75$; $\mathrm{N}, 6.51 \%) ; \delta_{\mathrm{H}} 3.53(3 \mathrm{H}, \mathrm{s}), 3.87(3 \mathrm{H}, \mathrm{s}), 5.53(1 \mathrm{H}, \mathrm{d}$, $J=9.0)$ and $7.40(1 \mathrm{H}$, br d, $J=9.0)$.

5.2.1.5. $N$-Benzoyl- $\alpha$-bromoglycine methyl ester 7 h. Pale brown oil, $\delta_{\mathrm{H}} 3.91(3 \mathrm{H}, \mathrm{s}), 6.68(1 \mathrm{H}, \mathrm{d}, J=10.0)$, $7.15(1 \mathrm{H}$, br d, $J=10.0), 7.42-7.60(3 \mathrm{H}, \mathrm{m})$ and $7.81-$ $7.85(2 \mathrm{H}, \mathrm{m})$.

5.2.1.6. $N$-Benzoyl- $\alpha$-methoxyglycine methyl ester $8 \mathrm{~h}$. (85\% from 5h) Colorless solid from ethyl acetate/hexanes, $\mathrm{mp} 72-73^{\circ} \mathrm{C}$ (lit. ${ }^{28} 86-87^{\circ} \mathrm{C}$ ) (Found: $\mathrm{C}, 59.23 ; \mathrm{H}$, 5.98; $\mathrm{N}, 6.51 . \mathrm{C}_{11} \mathrm{H}_{13} \mathrm{NO}_{4}$ requires $\mathrm{C}, 59.19 ; \mathrm{H}, 5.87 ; \mathrm{N}$, $6.27 \%) ; \delta_{\mathrm{H}} 3.56(3 \mathrm{H}, \mathrm{s}), 3.87(3 \mathrm{H}, \mathrm{s}), 5.78(1 \mathrm{H}, \mathrm{d}$, $J=8.5), 7.12(1 \mathrm{H}$, br d, $J=8.5), 7.44-7.59(3 \mathrm{H}, \mathrm{m})$ and 7.83-7.86 (2H, m); $m / z$ (EI) $223\left(\mathrm{M}^{+\bullet}, 0.6 \%\right), 164$ (45), $105(100)$ and $77(40)$.

5.2.1.7. $\quad N$-(4-Fluorobenzoyl)- $\alpha$-bromoglycine methyl ester 7i. Pale brown oil, $\delta_{\mathrm{H}} 3.93(3 \mathrm{H}, \mathrm{s}), 6.66(1 \mathrm{H}, \mathrm{d}$, $J=10.0), 6.95(1 \mathrm{H}$, br d, $J=10.0), 7.14(2 \mathrm{H}, \mathrm{d}, J=9.0)$ and $7.19(2 \mathrm{H}, \mathrm{d}, J=9.0)$.

5.2.1.8. $N$-(4-Fluorobenzoyl)- $\alpha$-methoxyglycine methyl ester $\mathbf{8 i}$. (87\% from $\mathbf{5 i}$ ) Colorless solid from ethyl acetate/hexanes, $\mathrm{mp} 98-100^{\circ} \mathrm{C}$ (Found: C, 54.85; H, 5.09; $\mathrm{N}, 6.01 . \mathrm{C}_{11} \mathrm{H}_{12} \mathrm{FNO}_{4}$ requires $\mathrm{C}, 54.75 ; \mathrm{H}, 5.02 ; \mathrm{N}$, $5.81 \%) ; \delta_{\mathrm{H}} 3.54(3 \mathrm{H}, \mathrm{s}), 3.86(3 \mathrm{H}, \mathrm{s}), 5.76(1 \mathrm{H}, \mathrm{d}$, $J=9.0), 6.85(1 \mathrm{H}, \mathrm{br} \mathrm{d}, J=9.0)$ and $7.10-7.20(4 \mathrm{H}, \mathrm{m})$.

5.2.1.9. $\quad N$-(Pentafluorobenzoyl)- $\alpha$-bromoglycine methyl ester $7 \mathbf{j}$. Pale brown oil, $\delta_{\mathrm{H}} 3.82(3 \mathrm{H}, \mathrm{s}), 6.57$ $(1 \mathrm{H}, \mathrm{d}, J=5.0)$ and $6.73(1 \mathrm{H}$, br d, $J=5.0)$. 
5.2.1.10. $\quad N$-(Pentafluorobenzoyl)- $\alpha$-methoxyglycine methyl ester $8 \mathbf{j}$. (77\% from $\mathbf{5 j}$ ) Colorless solid from ethyl acetate/hexanes, $\mathrm{mp} 104-105^{\circ} \mathrm{C}$ (Found: $\mathrm{C}, 42.28 ; \mathrm{H}$, 2.63; N, 4.57. $\mathrm{C}_{11} \mathrm{H}_{8} \mathrm{~F}_{5} \mathrm{NO}_{4}$ requires $\mathrm{C}, 42.16 ; \mathrm{H}, 2.57$; $\mathrm{N}, 4.47 \%) ; \delta_{\mathrm{H}} 3.55(3 \mathrm{H}, \mathrm{s}), 3.86(3 \mathrm{H}, \mathrm{s}), 5.71(1 \mathrm{H}, \mathrm{d}$, $J=9.0)$ and $7.40(1 \mathrm{H}$, br d, $J=9.0)$.

5.2.1.11. $N$-Trifluoromethanesulfonyl- $\alpha$ - $(N$-succinimydyl)glycine methyl ester 18. (98\%) (Found $\mathrm{m} / z$ (EI) 259.0000. $\mathrm{C}_{6} \mathrm{H}_{6} \mathrm{~F}_{3} \mathrm{~N}_{2} \mathrm{O}_{4} \mathrm{~S}\left(\mathrm{M}^{+}-\mathrm{CO}_{2} \mathrm{Me}\right)$ requires $\mathrm{m} / \mathrm{z}$ 258.9999); $\delta_{\mathrm{H}} 2.83(4 \mathrm{H}, \mathrm{s}), 3.85(3 \mathrm{H}, \mathrm{s}), 6.08(1 \mathrm{H}, \mathrm{d}$, $J=9.0)$ and $7.75(1 \mathrm{H}$, br d, $J=9.0) ; \delta_{\mathrm{C}} 28.0,54.5,58.3$, $119.8(\mathrm{q}, J=319), 164.8$ and $175.1 ; \mathrm{m} / z$ (EI) $259\left(\mathrm{M}^{+\bullet}-\right.$ $\left.\mathrm{CO}_{2} \mathrm{Me}, 100 \%\right), 221(12), 162(12)$ and $69(24) ; m / z(\mathrm{ES})$ (+ve) $319\left(\mathrm{M}+\mathrm{H}^{+}\right) ; m / z$ (ES) (-ve) $317\left(\mathrm{M}-\mathrm{H}^{+}\right)$.

5.2.2. Treatment of mixtures of the amino acid derivatives $5 \mathrm{c}, 5 \mathrm{~d}, \mathbf{5 g}, \mathbf{5 h}, \mathbf{5 i}, \mathbf{5 j}$ and 15 with NBS. Equimolar mixtures of $\mathbf{5 c}$ and $\mathbf{5 d}, \mathbf{5 c}$ and $\mathbf{5 h}, \mathbf{5 c}$ and $\mathbf{5 i}, \mathbf{5 c}$ and $\mathbf{5 j}$, $\mathbf{5 d}$ and $\mathbf{5 j}, 5 \mathbf{d}$ and $\mathbf{5 g}$, and $\mathbf{5 g}$ and $\mathbf{1 5}$, were treated with NBS ( 1 mol equiv.) in $\mathrm{CCl}_{4}$, in the presence of $N$-tertbutylbenzamide ( 0.1 mol equiv.) as an internal standard, under the conditions used for the reactions of $\mathbf{5 c}$, 5d, 5g, 5h, 5i and 5j described above. ${ }^{1} \mathrm{H}$ NMR spectroscopic analysis of the product mixtures was used to determine the relative rates of reaction, as reported previously, ${ }^{15}$ and the results are shown in Table 2 . Within the limits of detection, with $\mathbf{5 d}$ and $\mathbf{5 g}$, the trifluoroacetamide $\mathbf{5 d}$ was quantitatively converted to the bromide 7d, while the sulfonamide $\mathbf{5 g}$ was inert. With $\mathbf{5 g}$ and $\mathbf{1 5}$, the sulfonamide $\mathbf{5 g}$ was quantitatively converted to the succinimide $\mathbf{1 8}$, while the phthalimide 15 was inert. On this basis the relative rates of reaction of $\mathbf{5 d}, \mathbf{5 g}$ and $\mathbf{1 5}$ were determined to be $1:<0.1:<0.01$.

5.2.3. $N$-Trifluoromethanesulfonylglycylglycine methyl ester 19a. Glycylglycine $(0.80 \mathrm{~g}, 6.1 \mathrm{mmol})$ was added to methanol $(20 \mathrm{ml})$ which had been pretreated with thionyl chloride $(0.85 \mathrm{~g}, 7.1 \mathrm{mmol})$ and the mixture was let stand overnight, then it was concentrated under reduced pressure, to yield a white powder. The powder was dissolved in methanol and the solution was concentrated under reduced pressure. The residual solid was suspended in dichloromethane $(20 \mathrm{ml})$ and triethylamine (1.26 g, $12.5 \mathrm{mmol})$ was added with stirring. The suspension was cooled to $-78^{\circ} \mathrm{C}$ and trifluoromethanesulfonic anhydride (1.67 g, $5.9 \mathrm{mmol})$ in dichloromethane $(10 \mathrm{ml})$ was added dropwise, then the mixture was allowed to warm to room temperature and let stand overnight. The resultant solution was washed with dilute hydrochloric acid $(2 \times 10 \mathrm{ml})$ and saturated aqueous sodium chloride $(2 \times 10 \mathrm{ml})$, dried over magnesium sulfate and concentrated under reduced pressure, to give the title compound 19a as a pale yellow powder $(0.29 \mathrm{~g}, 18 \%) \mathrm{mp} 121^{\circ} \mathrm{C}$ (Found: C, 25.96; H, 3.22; N, 10.08. $\mathrm{C}_{6} \mathrm{H}_{9} \mathrm{~F}_{3} \mathrm{~N}_{2} \mathrm{O}_{5} \mathrm{~S}$ requires $\mathrm{C}, 25.90 ; \mathrm{H}, 3.26 ; \mathrm{N}$, $10.07 \%) ; \delta_{\mathrm{H}} 3.80(3 \mathrm{H}, \mathrm{s}), 4.02(2 \mathrm{H}, \mathrm{d}, J=5.0), 4.11(2 \mathrm{H}$, $\mathrm{d}, J=5.0), 6.17(1 \mathrm{H}$, br t,$J=5.0)$ and $6.32(1 \mathrm{H}$, br t, $J=5.0) ; \delta_{\mathrm{C}} 41.0,45.7,52.1,119.6(\mathrm{q}, J=320), 167.8$ and $170.0 ; \mathrm{m} / z$ (EI) $279\left(\mathrm{M}+\mathrm{H}^{+}, 11 \%\right), 219$ (100), 209 (29), 191 (11), 162 (60), 133 (17), $116(72)$ and 88 (99).
5.2.4. (S)-N-Trifluoromethanesulfonylvaline methyl ester 20a. (S)-Valine was treated with methanol which had been pretreated with thionyl chloride, and the crude product ester was treated with trifluoromethanesulfonic anhydride, as described above for the synthesis of the glycylglycine derivative 19a, to give the title compound 20a as colorless crystals $(54 \%) \mathrm{mp} 43-45^{\circ} \mathrm{C}$ (lit. ${ }^{29} 44$ $\left.46^{\circ} \mathrm{C}\right) ;[\alpha]_{\mathrm{D}}^{25}=-39.4(c 0.50, \mathrm{MeOH}) ; \delta_{\mathrm{H}} 0.92(3 \mathrm{H}, \mathrm{d}$, $J=7.0), 1.04(3 \mathrm{H}, \mathrm{d}, J=7.0), 2.21(1 \mathrm{H}, \mathrm{m}), 3.81(3 \mathrm{H}, \mathrm{s})$, $4.07(1 \mathrm{H}, \mathrm{dd}, J=4.5,9.5)$ and $5.48(1 \mathrm{H}, \mathrm{br} \mathrm{d}, J=9.5)$; $\delta_{\mathrm{C}} 17.5,19.2,32.0,53.5,62.9,120.0(\mathrm{q}, J=320)$ and 171.7 .

5.2.5. $N$-Trifluoromethanesulfonylphenylalanine methyl ester 21a. Phenylalanine $(0.98 \mathrm{~g}, 5.9 \mathrm{mmol})$ was treated with methanol which had been pretreated with thionyl chloride, and the crude product ester was treated with trifluoromethanesulfonic anhydride, as described above for the synthesis of the glycylglycine derivative 19a, to give the title compound 21a as a colourless powder ( 350 $\mathrm{mg}, 19 \%$ ), $\mathrm{mp} 45-46^{\circ} \mathrm{C}$ from hexane (Found: $\mathrm{C}, 42.73$; $\mathrm{H}, 3.68 ; \mathrm{N}, 4.45 . \mathrm{C}_{11} \mathrm{H}_{12} \mathrm{~F}_{3} \mathrm{NO}_{4} \mathrm{~S}$ requires $\mathrm{C}, 42.45 ; \mathrm{H}$, $3.89 ; \mathrm{N}, 4.50 \%$.); $\delta_{\mathrm{H}} 3.12(1 \mathrm{H}, \mathrm{dd}, J=6.0,13.5), 3.18$ $(1 \mathrm{H}, \mathrm{dd}, J=6.0,13.5), 3.77(3 \mathrm{H}, \mathrm{s}), 4.50(1 \mathrm{H}, \mathrm{t}, J=6.0)$; $5.77(1 \mathrm{H}, \mathrm{br}), 7.12-7.15(2 \mathrm{H}, \mathrm{m})$ and $7.29-7.34(3 \mathrm{H}, \mathrm{m})$; $\delta_{\mathrm{C}} 40.0,53.5,58.3,115.6(\mathrm{q}, J=320), 128.3,129.4$, $129.9,134.4$ and $170.9 ; \mathrm{m} / z$ (EI) $311\left(\mathrm{M}^{+}, 6 \%\right), 252$ (61), 182 (19), 163 (38), 162 (100), 131 (41), 119 (61), 118 (73), 103 (22), 92 (52), 91 (55), 77 (15), 69 (56) and $65(68)$.

5.2.6. $\quad N$-Trifluoromethanesulfonylglycyl- $\alpha$-methoxyglycine methyl ester 19c. A mixture of $N$-trifluoromethanesulfonylglycylglycine methyl ester 19 a $(50 \mathrm{mg}$, $0.18 \mathrm{mmol})$ and NBS (35 mg, $0.20 \mathrm{mmol})$ in $\mathrm{CCl}_{4}$ and $\mathrm{CH}_{2} \mathrm{Cl}_{2}(1: 3, \mathrm{v} / \mathrm{v}, 5 \mathrm{ml})$ was heated at reflux for $4 \mathrm{~h}$ under nitrogen in a quartz tube whilst being irradiated with a sunlamp. The mixture was then allowed to cool to room temperature, before being filtered, to afford a solution of the bromide $19 \mathrm{~b} ; \delta_{\mathrm{H}} 3.89(3 \mathrm{H}, \mathrm{s}), 4.09(2 \mathrm{H}$, $\mathrm{d}, J=5.5), 6.42(1 \mathrm{H}, \mathrm{d}, J=10.0), 6.75(1 \mathrm{H}, \mathrm{br} \mathrm{t}, J=5.5)$ and $7.79(1 \mathrm{H}, \mathrm{d}, J=10.0)$. The yield of the bromide 19b was determined to be $92 \%$ through the addition of $N$-tert-butylbenzamide as an external standard.

Methanol $(1 \mathrm{ml})$ was added to the solution of the bromide 19b and the mixture was stirred for $1 \mathrm{~h}$ at room temperature before it was concentrated under reduced pressure. Chromatography of the residue afforded the title compound $19 \mathbf{c}$ as colorless needles (20 $\mathrm{mg}, 36 \%), \mathrm{mp} 94-95^{\circ} \mathrm{C}$ from ethyl acetate/hexanes (Found: $m / z$ (EI) 277.0108. $\mathrm{C}_{6} \mathrm{H}_{8} \mathrm{~F}_{3} \mathrm{~N}_{2} \mathrm{O}_{5} \mathrm{~S}\left(\mathrm{M}^{+}{ }^{\bullet} \mathrm{OMe}\right)$ requires $\mathrm{m} / z 277.0106) ; \delta_{\mathrm{H}} 3.49(3 \mathrm{H}, \mathrm{s}), 3.85(3 \mathrm{H}, \mathrm{s})$, $4.05(2 \mathrm{H}, \mathrm{d}, J=5.0), 5.54(1 \mathrm{H}, \mathrm{d}, J=9.0), 6.04(1 \mathrm{H}, \mathrm{br}$ $\mathrm{t}, J=5.0)$ and $6.82(1 \mathrm{H}$, br d, $J=9.0) ; \delta_{\mathrm{C}} 46.2,53.9$, $57.8,120.0(\mathrm{q}, J=320), 167.5$ and $168.5 ; \mathrm{m} / z(\mathrm{EI}) 293$ $\left(\mathrm{M}^{+}-\mathrm{Me}, 12 \%\right), 279$ (23), 278 (50), 277 (64), 250 (11), 249 (83), 162 (22), 104 (14) and 103 (54); $m / z$ (ES) (+ve) $309\left(\mathrm{M}+\mathrm{H}^{+}\right)$. The regioselectivity of methoxylation was determined by mass spectrometry (Found: $m / z$ (EI) 103.0396. $\mathrm{C}_{4} \mathrm{H}_{7} \mathrm{O}_{3}\left(\mathrm{CH}(\mathrm{OMe}) \mathrm{CO}_{2} \mathrm{Me}^{+\bullet}\right)$ requires $\mathrm{m} / \mathrm{z}$ 103.0395). 
5.2.7. (S)- $\mathrm{N}$-Trifluoromethanesulfonyl-3-bromovaline methyl ester 20b. A mixture of the valine derivative 20a $(0.20 \mathrm{~g}, 0.76 \mathrm{mmol})$ and NBS $(135 \mathrm{mg}, 0.76 \mathrm{mmol})$ in carbon tetrachloride $(5 \mathrm{ml})$ was heated at reflux for $5 \mathrm{~h}$ whilst being irradiated with a sunlamp. The mixture was then allowed to cool to room temperature, before it was filtered. The filtrate was concentrated under reduced pressure and the residue was subjected to chromatography, to give the title compound $\mathbf{2 0 b}$ as colorless crystals $(180 \mathrm{mg}, 69 \%), \mathrm{mp} 47.5-48^{\circ} \mathrm{C}$ from hexanes (Found: C, 24.62; H, 3.08; N, 4.20. $\mathrm{C}_{7} \mathrm{H}_{11} \mathrm{BrF}_{3} \mathrm{NO}_{4} \mathrm{~S}$ requires $\mathrm{C}, 24.57 ; \mathrm{H}, 3.24 ; \mathrm{N}, 4.09 \%$. $) ;[\alpha]_{\mathrm{D}}^{25}=-65.6(c$ $0.75, \mathrm{MeOH}) ; \delta_{\mathrm{H}} 1.91(3 \mathrm{H}, \mathrm{s}), 1.93(3 \mathrm{H}, \mathrm{s}), 3.87(3 \mathrm{H}, \mathrm{s})$, $4.05(1 \mathrm{H}, \mathrm{d}, J=10.0)$ and $5.94(1 \mathrm{H}, \mathrm{d}, J=10.0) ; \delta_{\mathrm{C}}$ $32.3,32.9,53.7,62.7,66.7,119.9(\mathrm{q}, J=320)$ and 168.5 ; $m / z$ (EI) $342\left(\mathrm{M}^{+\bullet},{ }^{81} \mathrm{Br}, 7 \%\right), 340\left(\mathrm{M}^{+\bullet},{ }^{79} \mathrm{Br}, 7\right), 284$ (49), 282 (62), 262 (37), 221 (67), 220 (33), 202 (100), 149 (23), 123 (37), 121 (40), 88 (52) and 69 (40).

5.2.8. Treatment of $(S)$ - $N$-trifluoromethanesulfonylvaline methyl ester 20a with sulfuryl chloride. To a solution of $(S)$ - $N$-trifluoromethanesulfonylvaline methyl ester 20a $(100 \mathrm{mg}, 0.38 \mathrm{mmol})$ in carbon tetrachloride $(5 \mathrm{ml})$ was added sulfuryl chloride $(51 \mathrm{mg}, 0.38 \mathrm{mmol}$ ) and benzoyl peroxide (ca. $5 \mathrm{mg}$ ). The mixture was heated at reflux for $5 \mathrm{~h}$ under nitrogen whilst being irradiated with a sunlamp, then it was cooled and concentrated under reduced pressure. The residue was chromatographed to give unreacted starting material 20a (24 mg, 24\%), ( $S$ )- $N$-trifluoromethanesulfonyl-3-chlorovaline methyl ester 20d (31 mg, 27\%) as colorless crystals, mp 64 $65^{\circ} \mathrm{C}$ (Found: C, 28.50; H, 3.83; N, 4.89. $\mathrm{C}_{7} \mathrm{H}_{11} \mathrm{ClF}_{3} \mathrm{NO}_{4} \mathrm{~S}$ requires $\mathrm{C}, 28.24 ; \mathrm{H}, 3.72 ; \mathrm{N}, 4.71 \%$.); $[\alpha]_{\mathrm{D}}^{25}=-27.8(c 0.24, \mathrm{MeOH}) ; \delta_{\mathrm{H}} 1.73(3 \mathrm{H}, \mathrm{s}), 1.74(3 \mathrm{H}$, s), $3.85(3 \mathrm{H}, \mathrm{s}), 4.16(1 \mathrm{H}, \mathrm{br})$ and $5.95(1 \mathrm{H}, \mathrm{br}) ; \delta_{\mathrm{C}} 30.7$, $31.3,53.7,66.1,68.6,120.0(\mathrm{q} J=320)$ and $168.4 ; \mathrm{m} / \mathrm{z}$ (EI) 240 (11\%), 238 (49), 202 (100), 149 (47), 79 (52) and 77 (89); and a 1:1 mixture of diastereomers of $(2 S, 3 S)$ - and (2S,3R)- $N$-trifluoromethanesulfonyl-4chlorovaline methyl ester (46 $\mathrm{mg}, 41 \%)$ as a colorless solid, $\mathrm{mp} 52-71{ }^{\circ} \mathrm{C}$ (Found: $\mathrm{C}, 28.20 ; \mathrm{H}, 3.74 ; \mathrm{N}, 4.56$. $\mathrm{C}_{7} \mathrm{H}_{11} \mathrm{ClF}_{3} \mathrm{NO}_{4} \mathrm{~S}$ requires $\mathrm{C}, 28.24 ; \mathrm{H}, 3.72 ; \mathrm{N}, 4.71 \%$ ); $m / z(\mathrm{EI}) 300\left(\mathrm{M}+\mathrm{H}^{+}, 0.3 \%\right), 298\left(\mathrm{M}+\mathrm{H}^{+}, 0.8\right), 274(3)$, 272 (5), 240 (49), 238 (100), 220 (30), 202 (49) and 162 (51); one diastereomer had $\delta_{\mathrm{H}} 1.12(3 \mathrm{H}, \mathrm{d}, J=7.0), 2.49$ $(1 \mathrm{H}, \mathrm{m}), 3.55(2 \mathrm{H}, \mathrm{m}), 3.84(3 \mathrm{H}, \mathrm{s}), 4.33(1 \mathrm{H}, \mathrm{d}, J=4.5)$ and $5.82(1 \mathrm{H}, \mathrm{br}) ; \delta_{\mathrm{C}} 14.6,39.3,45.7,53.3,59.3,119.3$ (q, $J=320)$ and 170.1; the other diastereomer had $\delta_{\mathrm{H}}$ $1.00(3 \mathrm{H}, \mathrm{d}, J=7.0), 2.46(1 \mathrm{H}, \mathrm{m}), 3.46(1 \mathrm{H}, \mathrm{dd}, J=6.0$, $11.5), 3.56(1 \mathrm{H}, \mathrm{dd}, J=8.0,11.5), 3.85(3 \mathrm{H}, \mathrm{s}), 4.52$ $(1 \mathrm{H}, \mathrm{br} \mathrm{d}, J=4.5)$ and $5.60(1 \mathrm{H}, \mathrm{br}) ; \delta_{\mathrm{C}} 12.6,39.4,45.6$, $53.5,58.2,119.5(\mathrm{q}, J=320)$ and 170.5 . A ${ }^{1} \mathrm{H}$ NMR spectrum of the crude product mixture showed that the $\beta$-chlorovaline derivative and the diasteromers of the corresponding $\gamma$-chlorovaline derivative were present in the ratio $1.3: 1: 1$.

5.2.9. Treatment of the bromovaline derivative $20 \mathrm{~b}$ with tributyltin hydride. A mixture of the bromide 20b $(50$ $\mathrm{mg}, 0.15 \mathrm{mmol})$ and tributyltin hydride $(0.1 \mathrm{ml}, 3.7$ $\mathrm{mmol})$ in benzene $(10 \mathrm{ml})$ was heated at reflux under nitrogen for $6 \mathrm{~h}$, then it was cooled and concentrated under reduced pressure. Chromatography of the residue afforded the valine derivative $20 \mathrm{a}$ as colorless crystals $(17 \mathrm{mg}, 44 \%), \mathrm{mp} \quad 42-44^{\circ} \mathrm{C},[\alpha]_{\mathrm{D}}^{25}=-40.1 \quad(c \quad 0.09$, $\mathrm{MeOH})$. These data are consistent with those obtained above, using a sample prepared directly from $(S)$ valine.

5.2.10. $\quad N$-Trifluoromethanesulfonyl-3-bromophenylalanine methyl ester 21b. To a solution of $N$-trifluoromethanesulfonylphenylalanine methyl ester 21a (100 $\mathrm{mg}, 0.32 \mathrm{mmol})$ in carbon tetrachloride $(10 \mathrm{ml})$ was added NBS (64 mg, $0.35 \mathrm{mmol}$ ). The mixture was heated at reflux for $6 \mathrm{~h}$ under nitrogen whilst being irradiated with a sunlamp, then it was allowed to cool before it was filtered. The filtrate was concentrated under reduced pressure and the residue was chromatographed to give a 1:1 mixture of diastereomers of the title compound $\mathbf{2 1 b}$ as a colorless solid $(85 \mathrm{mg}$, $68 \%$ ), mp $113-126^{\circ} \mathrm{C}$ (Found: $\mathrm{C}, 33.98 ; \mathrm{H}, 2.60 ; \mathrm{N}$, 3.38. $\mathrm{C}_{11} \mathrm{H}_{11} \mathrm{BrF}_{3} \mathrm{NO}_{4} \mathrm{~S}$ requires $\mathrm{C}, 33.86 ; \mathrm{H}, 2.84 ; \mathrm{N}$, $3.59 \%) ; \delta_{\mathrm{H}} 3.79(3 \mathrm{H}, \mathrm{s}), 3.86(3 \mathrm{H}, \mathrm{s}), 4.51(1 \mathrm{H}, \mathrm{dd}$, $J=3.5,10.0), 4.71(1 \mathrm{H}, \mathrm{dd}, J=5.5,10.0), 5.31(1 \mathrm{H}, \mathrm{d}$, $J=5.5), 5.52(1 \mathrm{H}, \mathrm{d}, J=3.5), 5.83(1 \mathrm{H}, \mathrm{br} \mathrm{d}, J=10.0)$, $5.97(1 \mathrm{H}$, br $\mathrm{d}, J=10.0)$ and $7.37-7.47(10 \mathrm{H}, \mathrm{m}) ; \delta_{\mathrm{C}}$ $51.7,54.0,54.4,63.7,64.2,119.7$ (q, $J=320), 119.8$ (q, $J=320), 128.8,128.9,129.4,129.6,130.1,130.2,135.7$, 136.3, 168.6 and $168.8 ; \mathrm{m} / z$ (EI) $391\left(\mathrm{M}^{+\bullet}, 2 \%\right), 389$ $\left(\mathrm{M}^{+\bullet}, 2\right), 332$ (4), 330 (4), 310 (10), 251 (10), 250 (13), 242 (8), 240 (8), 192 (6), 171 (97), 169 (100), 118 (62), 117 (42), 105 (36), 91 (71) and 77 (22). Repeated chromatography afforded a single diastereomer $(23 \mathrm{mg}$, $18 \%) \mathrm{mp} 123-123.5^{\circ} \mathrm{C} ; \delta_{\mathrm{H}} 3.86(3 \mathrm{H}, \mathrm{s}), 4.51(1 \mathrm{H}, \mathrm{dd}$, $J=3.5,10.0), 5.52(1 \mathrm{H}, \mathrm{d}, J=3.5), 5.83(1 \mathrm{H}$, br d, $J=10.0)$ and $7.37-7.47(5 \mathrm{H}, \mathrm{m})$.

\section{References}

1. Williams, R. M. Synthesis of Optically Active $\alpha$-Amino Acids; Baldwin, J. E.; Magnus, P. D., Eds.; Organic Chemistry Series, Vol. 7; Pergamon Press: Oxford, 1989.

2. Seebach, D.; Beck, A. K.; Studer, A. In Modern Synthetic Methods; Ernst, B.; Leumann, C., Eds.; VCH: Weinheim, 1995; Vol. 7, pp. 1-178.

3. Easton, C. J. Chem. Rev. 1997, 97, 53.

4. Easton, C. J. In Radicals in Organic Synthesis; Renaud, P.; Sibi, M. P., Eds.; Wiley-VCH: Weinheim, 2001; Vol. 2, pp. 505-522.

5. Wessig, P. In Radicals in Organic Synthesis; Renaud, P.; Sibi, M. P., Eds.; Wiley-VCH: Weinheim, 2001; Vol. 2, pp. 523-537.

6. Easton, C. J.; Tan, E. W.; Hay, M. P. J. Chem. Soc. Chem. Commun. 1989, 385.

7. Easton, C. J.; Hutton, C. A.; Rositano, G.; Tan, E. W. J. Org. Chem. 1991, 56, 5614.

8. Easton, C. J.; Hutton, C. A.; Roselt, P. D.; Tiekink, E. R. T. Tetrahedron 1994, 50, 7327.

9. Easton, C. J.; Hutton, C. A.; Merrett, M. C.; Tiekink, E. R. T. Tetrahedron 1996, 52, 7025 .

10. Easton, C. J.; Hutton, C. A. Synlett 1998, 457.

11. Easton, C. J.; Fryer, N. L.; Ivory, A. J.; Tiekink, E. R. T. J. Chem. Soc., Perkin Trans. 1 1998, 3725. 
12. Henry, D. J.; Parkinson, C. J.; Mayer, P. M.; Radom, L. J. Phys. Chem. A 2001, 105, 6750.

13. Parkinson, C. J.; Mayer, P. M.; Radom, L. J. Chem. Soc., Perkin Trans. 2 1999, 2305.

14. Armstrong, D. A.; Yu, D.; Rauk, A. Can. J. Chem. 1996, 74, 1192.

15. Croft, A. K.; Easton, C. J.; Radom, L. J. Am. Chem. Soc. 2003, 125, 4119.

16. Easton, C. J.; Scharfbillig, I. M.; Tan, E. W. Tetrahedron Lett. 1988, 29, 1565.

17. Schulze, R.; Beckhaus, H.-D.; Rüchardt, C. Chem. Ber. 1993, 126, 1031.

18. Welle, F. M.; Beckhaus, H.-D.; Rüchardt, C. J. Org. Chem. 1997, 62, 552.

19. Yu, D.; Rauk, A.; Armstrong, D. A. J. Am. Chem. Soc. 1995, 117, 1789.

20. Frisch, M. J.; Trucks, G. W.; Schlegel, H. B.; Gill, P. M. W.; Johnson, B. G.; Robb, M. A.; Cheeseman, J. R.; Keith, T.; Petersson, G. A.; Montgomery, J. A.; Raghavachari, K.; Al-Laham, M. A.; Zakrzewski, V. G.; Ortiz, J. V.; Foresman, J. B.; Cioslowski, J.; Stefanov, B. B.; Nanayakkara, A.; Challacombe, M.; Peng, C. Y.; Ayala, P. Y.; Chen, W.; Wong, M. W.; Andres, J. L.; Replogle, E. S.; Gomperts, R.; Martin, R. L.; Fox, D. J.; Binkley, J. S.; Defrees, D. J.; Baker, J.; Stewart, J. P.; Head-Gordon, M.; Gonzalez, C.; Pople, J. A. Gaussian
94, Revision E.2; Gaussian, Inc.: Pittsburgh PA, 1995.

21. MOLPRO 96 is a package of ab initio programs written by H.-J. Werner and P. J. Knowles, with contributions from J. Almlöf, R. D. Amos, A. Berning, M. J. O. Deegan, F. Eckert, S. T. Elbert, C. Hampel, R. Lindh W. Meyer, A. Nicklass, K. Peterson, R. Pitzer, A. J. Stone, P. R. Taylor, M. E. Mura, P. Pulay, M. Schuetz, H. Stoll, T. Thorsteinsson, and D. L. Cooper, (C) University of Birmingham: Birmingham, UK, 1996.

22. Scott, A. P.; Radom, L. J. Phys. Chem. 1996, 100, 16502.

23. Still, W. C.; Kahn, M.; Mitra, A. J. Org. Chem. 1978, 43, 2923.

24. Huang, H. T.; Niemann, C. J. Am. Chem. Soc. 1952, 74, 4634.

25. Applewhite, T. H.; Martin, R. B.; Niemann, C. J. Am. Chem. Soc. 1958, 80, 1457.

26. Burgess, V. A.; Easton, C. J.; Hay, M. P. J. Am. Chem. Soc. 1989, 111, 1047.

27. Legall, P.; Sawhney, K. N.; Conley, J. D.; Kohn, H. Int. J. Pept. Protein Res. 1988, 32, 279.

28. Chemiakine, M. M.; Tchaman, E. S.; Denisova, L. I.; Ravdel, G. A.; Rodionow, W. J. Bull. Soc. Chim. Fr. 1959, 530 .

29. (a) Sartor, D.; Saffrich, J.; Helmchen, G. Synlett 1990, 197; (b) Helmchen, G. University of Heidelberg, personal communication. 